\title{
INOVASI LAYANAN SEPASAR PEDAS (SEKOLAH PASAR RAKYAT PEDAGANG CERDAS) DALAM MENINGKATKAN EKSISTENSI PASAR TRADISIONAL DI DINAS KOPERASI PERINDUSTRIAN DAN PERDAGANGAN KOTA MALANG
}

\author{
Fitri Dwi Laraswati \\ S1 Ilmu Administrasi Negara, Jurusan Administrasi Publik, Fakultas Ilmu Sosial dan Hukum \\ Universitas Negeri Surabaya \\ Email: fitri.17040674018@mhs.unesa.ac.id \\ Fitrotun Niswah \\ S1 Ilmu Administrasi Negara, Jurusan Administrasi Publik, Fakultas Ilmu Sosial dan Hukum \\ Universitas Negeri Surabaya \\ Email: fitrotunniswah@unesa.ac.id
}

\begin{abstract}
Abstrak
Dinas Koperasi Perindustrian dan Perdagangan Kota Malang telah menciptakan sebuah inovasi pelayanan untuk pedagang pasar tradisional melalui program Sepasar Pedas. Inovasi ini bertujuan untuk meningkatkan kompetensi dan wawasan pedagang pasar rakyat di era globalisasi serta meningkatkan eksistensi pasar tradisional. Jenis penelitian yang digunakan adalah penelitian deskriptif dengan pendekatan kualitatif. Teknik pengumpulan data melalui teknik wawancara, observasi, dokumentasi, dan studi pustaka. Teknik analisis data terdiri dari pengumpulan data, reduksi data, penyajian data, dan penarikan kesimpulan. Fokus penelitian menggunakan kapasitas inovasi yaitu budaya inovatif, kepemimpinan, pengetahuan ahli, keterlibatan stakeholders, dan desain kerja inovatif. Hasil dari penelitian ini menunjukan dari komponen budaya inovatif Diskopindag Kota Malang setiap minggunya selalu memberikan materi baru untuk Sepasar pedas. Komponen, kepemimpinan Diskopindag Kota Malang bertanggung jawab sebagai koordinator yang memanjemen seluruh kegiatan yang berkaitan dengan program Sepasar Pedas. Pada Komponen pengetahuan ahli yaitu pegawai di Diskopindag Kota Malang dibidang perdagangan, yang didalamnya terdiri dari seksi atau sub bidang yang nantiya membantu Sepasar Pedas. Komponen keterlibatan stakeholders Diskopindag Kota Malang melibatkan pihak-pihak eksternal seperti Dinas Kesehatan dan Bank Jatim. Dan pada komponen desain kerja inovatif Diskopindag Kota Malang dengan telah melakukan kerja sama yang baik dan pedgang memiliki kesadaran yang tinggi akan pentingnya inovasi ini. Saran yaitu untuk kedepannya Sepasar Pedas ini dapat diterapkan di semua pasar di Kota Malang.

Kata Kunci : inovasi pelayanan, sepasar pedas, pedagang pasar tradisional
\end{abstract}

\begin{abstract}
The Department of Industry and Trade Cooperatives of Malang City has created an innovative service for traditional market traders through the Sepasar Pedas program. This innovation aims to improve the competence and insight of traditional market traders in the era of globalization and increase the existence of traditional markets. This type of research is a descriptive study with a qualitative approach. Data collection techniques through interview techniques, observation, documentation, and literature study. Data analysis techniques consist of data collection, data reduction, data presentation, and drawing conclusions. The research focus uses innovation capacities, namely Innovative Culture, Leadership, Expert Knowledge, Stakeholders Engagement, and Innovative Work Design. The results of this study indicate the components of the Innovative Culture Diskopindag Malang City always provide new material for Sepasar spicy. The Leadership Component of Malang City Diskopindag is responsible for coordinating all activities related to the Sepasar Pedas program. In the Expert Knowledge component, employees at Diskopindag Malang City in the field of trade, which consists of sections or sub-fields which later help the Spicy Market. The Stakeholders Engagement component of Malang City Diskopindag involves external parties such as the Health Office and Bank Jatim. And in the Innovative Work Design component of the Malang City Diskopindag and cooperation with good
\end{abstract}


cooperation and traders have a high awareness of the importance of this innovation. Suggestions are that in the future Sepasar Pedas can be applied in all markets in Malang City.

Keyword : service innovation, sepasar pedas, traditional market traders

\section{PENDAHULUAN}

Dalam kehidupan bermsyarakat, tentunya tidak lepas dari kegitan pelayanan. Pelayanan sangat diperlukan dalam berbagai bidang. Begitu pula dengan pelayanan publik yang diberikan oleh pemerintah. Pelayanan umum tidak lepas dari arti kepentingan umum, yaitu: Setiap kegiatan yang bertujuan untuk memenuhi kepentingan orang banyak. Kepentingan umum diartikan sebagai himpunan kepentingan pribadi yang telah bersatu dan tidak bertentangan dengan norma masyarakat dan aturan yang berlaku.(Suriyani, 2017) Tujuan utama penyelenggaraan pelayanan publik adalah membantu menyelesaikan berbagai masalah dan kepentingan masyarakat serta untuk memenuhi kebutuhan masyarakat. Untuk menyediakan pelayanan publik yang berkualitas bagi masyarakat memang tidak mudah, pemerintah perlu membuat pelayanan yang sesuai.(Haqie, Nadiah, \& Ariyani, 2020) Agar masyarakat dapat merasakan kenyamanan dari pelayanan yang disuguhkan oleh pemerintah. Mengingat begitu pentingnya pelayanan publik bagi masyarakat, maka pemerintah perlu terus berupaya memberikan pelayanan yang baik dan mudah didapatkan oleh masyarakat. Sehingga pemerintah harus melakukan inovasi setiap tahunnya dalam rangka meningkatkan kualitas pelayanan.

"Governments struggle to understand how technologies can be used to innovate in the development and delivery of public sectors.

(Pemerintah berusaha keras untuk memahami bagaimana caranya teknologi dapat digunakan untuk berinovasi dalam pengembangan dan penyampaian sektor publik).(Pym, Taylor, \& Tofts, 2007)

Terciptanya suatu inovasi merupakan ukuran nyata keberhasilan otonomi daerah(Anggraeny, 2013).Inovasi pelayanan, dibutuhkan sebagai terobosan baru dalam upaya meningkatkan efisiensi pelayanan terhadap masyarakat. Konsep inovasi dalam sektor publik mulai dipraktikkan di berbagai negara berkembang karena adanya perkembangan teknologi canggih yang pesat.(Eprilianto, Sari, \& Saputra, 2019) Dengan adanya inovasi pelayanan publik, maka lebih mudah untuk menggabungkan berbagai layanan yang ada sehingga lebih efektif dan efisien. Usaha dalam melakukan inovasi tersebut dapat mewujudkan birokrasi yang tepat.

Setiap tahunnya Pemerintah Provinsi Jawa Timur mengadakan kompetisi Top Inovasi Pelayanan Publik. Tahun 2019 lalu terdapat Top 25 Inovasi Pelayanan Publik yang diberikan penghargaan. Salah satunya yaitu Dinas Koperasi Perindustrian dan Perdagangan Kota Malang. Inovasi itu dituangkan dalam Program SEPASAR PEDAS (Sekolah Rakyat Pedagang Cerdas).

Inovasi tersebut tercetus mulanya melihat kemajuan ekonomi dan pertumbuhan wilayah yang berdampak pada beberapa sistem kegiatan, salah satunya yaitu kegiatan perdagangan.(Arianty, 2013). Dan dalam kegiatan perdagangan, pasar merupakan sarana utama untuk menadah kegiatan tersebut. Dalam hal ini sistem manajemen pasar yang baik dan kualitas interaksi serta fasilitas fisik yang memadai sangat diperlukan dalam menunjang kenyamanan masyarakat untuk melakukan transaksi di pasar.

Kehadiran pasar tradisional dan pasar modern telah melekat pada kehidupan masyarakat di kota. Dimana sebagian dari kita masih membutuhkan pasar tradisional. Setiyanto (dalam Djau, 2009) mengemukakan bahwa pasar tradisional mempunyai kapasitas sebagai ikon pada suatu daerah. Namun dengan hadirnya pasar modern, pasar tradisional menjadi semakin memudar eksistensinya. Hal ini dapat dililihat dari kondisi pasar tradisional yang tidak tersusun cukup baik, misalnya masih ada beberapa pasar tumpah yang merambak di sekitar pasar, dan lingkungan pasar yang kurang bersih.(Andriani, Maritfa Nika \& Ali, 2013)

Tidak dapat dipungkiri, jika pasar tradisional tidak diperhatikan kualitas dan keberadaanya, semakin lama akan tergeserkan oleh 
pasar modern, supermarket, mall dan pusat perbelanjaan modern lainnya. Oleh karenanya penting mempertahankan keberadaan pasar tradisional di tengah persaingan pasar bebas, agar pilar ekonomi tetap berjalan. Dimana untuk mempertahankan itu perlu adanya penguatan pasar dan revitalisasi pasar guna meningkatkan citra pasar tradisional.

Kemudian dengan adanya globalisasi serta perkembangan teknologi sekarang ini, persaingan antara pasar tradisional dan retail modern tidak bisa dihindari.Tentunya penting bagi masyarakat yang memiliki usaha atau yang berdagang siap bersaing dengan dunia luar. Apalagi dengan berkembangnya pasar modern dan sistem penjualan online, bukan tidak mungkin pedagang pasar tradisional akan meredup. Oleh karena itu dibutuhkan inovasiinovasi baru atau ide kreatif yang harus dimnculkan untuk mengatasi persaingan pasar bebas saat ini.

Dalam hal ini Dinas Koperasi Perindustrian dan Perdagangan Kota Malang mencoba memberikan ide baru terkait pengembangan pasar rakyat atau pasar tradisional yang sasaran utamanya adalah pedagang pasar. Adanya program SEPASAR PEDAS ini akan memberikan pengetahuan dan wawasan kepada pedagang pasar rakyat melalui training, pembelajaran, pembimbingan, dan bentuk lainnya. Tujuan dari adanya inovasi ini yaitu untuk mengembangkan kemampuan dan daya saing tinggi antar pedagang pasar tradisional di tengah-tengah persaingan pasar bebas serta dapat melek teknologi di era yang sekarang ini.

"The knowledge on the traditional market sellers' acceptance on an electronic system will help government in designing smart city concept.

(Pengetahuan tentang pedagang pasar tradisional dalam penerimaan pada sistem elektronik akan membantu pemerintah masuk merancang konsep kota pintar)"(Nugroho, S, Nurhaeni, \& Utami, 2017).

SEPASAR PEDAS ini dimulai sejak tahun 2017. Inovasi ini diterapkan pertama kali di Pasar Oro-oro Dowo Kota Malang. Yang mana pasar ini merupakan pasar icon Jawa Timur, karena disana merupakan pasar yang dilakukan revitalisasi pertama kali yang dibiayai oleh pemerintah pusat. Kemudian pasar kedua yang diterapkan inovasi ini yaitu di Pasar Dinoyo. Namun untuk pasar-pasar yang lain masih belum dilaksanakan inovasi ini

Ibu Eka selaku Kepala Seksi Bidang Pengendalian dan Pengawasan Dinas Koperasi Perindustrian dan Perdagangan Kota Malang mengatakan, Pasar Oro-oro Dowo memiliki banyak prestasi, salah satunya yaitu Pasar SNI, yang merupakan pasar dengan produk-produk yang dijual sudah berstandart SNI. SNI Pasar Rakyat disusun sebagai acuan dalam mengatur dan membangun pasar rakyat, serta memberdayakan komunitas Pasar Rakyat, sehingga Pasar Rakyat dapat dikelola secara profesional, memiliki kualitas dan fasilitas yang memadai untuk terciptanya pasar rakyat yang bersih, sehat, aman dan nyaman.(Sembiring, 2018) Pasar ini juga ditetapkan oleh Kementrian Perdagangan Republik Indonesia sebagai pasar tertib ukur, yang mana setiap bulannya timbangan para pedagang rutin ditera.

Untuk mengimbangi prestasi yang diraih oleh Pasar Oro-Oro Dowo, maka perlu memberikan bekal wawasan tentang manajemen pasar yang baik kepada para pedagang, agar pedagang pasar mampu memanfaatkan peluang di era globalisasi dan mampu memnfaatkan perkembangan teknologi.

Mulanya pedagang di Pasar Oro-Oro Dowo yang mengikuti kegiatan pada inovasi ini hanya 50 orang pedagang saja dari 180 kios . Karena inovasi ini merupakan hal yang baru bagi mereka. Dimana sebelumnya aktivitas keseharian mereka hanya sebatas melakukan transaksi antara penjual dan pembeli. Namun setelah 50 orang pedagang yang mengikuti kegiatan ini dan merasakan dampaknya, pedagang lain pun yang sebelumnya enggan mengikuti kegiatan ini, menjadi antusias dalam menjalankan program ini. Dan sampai saat ini dari 180 kios, hampir semuanya dari setiap pedagang disetiap kiosnya mau mengikuti kegiatan dalam inovasi SEPASAR PEDAS ini.

Dilansir dari Jatim Times.com(Firdausi, 2019) inovasi SEPASAR PEDAS ini dalam pelaksanaannya akan memberikan beragam materi, yakni tentang kesehatan dan keamanan pangan, tertib ukur timbangan, stabilitas harga, dan perbankan. Serta yang sudah lulus dari sekolah 
pasar rakyat ini akan di berikan sertifikat khusus. Harapannya, dengan program inovasi tersebut pedagang pasar rakyat dapat bersaing dan bisa memberikan keyakinan lebih kepada konsumen agar tetap berbelanja ke pasar dengan rasa aman dan nyaman.

Selain semakin maraknya persaingan pasar bebas yang mengakibatkan pedagang pasar rakyat mengalami penurunan pendapatan, peneliti juga tertarik mengambil judul ini karena, inovasi SEPASAR PEDAS merupakan inovasi pertama di Jawa Timur yang memfokuskan pada pengembangan pengatahuan pedagang pasar rakyat atau pasar tradisional, sehingga dapat meningkatkan eksistensi pasar tradisional, dan memaksimalkan peran pasar dalam kemajuan ekonomi. Kemudian diharapkan inovasi ini dapat memberikan contoh bagi daerah lain, untuk selalu mengembangkan inovasinya dalam hal pelayanan.

Berdasarkan latar belakang masalah yang diuraikan sebelumnya, maka perumusan masalah dalam penelitian ini adalah Bagaimana Inovasi Layanan Sepasar Pedas (Sekolah Pasar Rakyat Pedagang Cerdas) dalam meningkatkan eksistensi pasar tradisional di Dinas Koperasi Perindustrian dan Perdagangan Kota Malang. Dan tujuan adanya penelitian ini yaitu untuk mendeskripsikan dan menganalisis Inovasi Sekolah Pasar Rakyat Pedagang Cerdas sebagai wujud peningkatan eksistensi pasar tradisional oleh Dinas Koperasi Perindustrian dan Perdagangan Kota Malang.

\section{METODE}

Pada penelitian tentang "Inovasi Layanan SEPASAR PEDAS (Sekolah Pasar Rakyat Pedagang Cerdas) di Dinas Koperasi Perindustriandan Perdagangan Kota Malang merupakan penelitian deskriptif dengan menggunakan pendekatan penelitian kualitatif(Soewadji, 2012). Jenis data kualitatif merupakan data yang berbentuk kata, kalimat, skema dan gambar. Pendekatan kualitatif sengaja dipilih untuk mendapatkan informasi data yang lebih detail, valid dan akurat serta mendalam(Sugiyono, 2012).

Fokus penelitian Inovasi Layanan SEPASAR PEDAS (Sekolah Pasar Rakyat Pedagang Cerdas) di Dinas Koperasi
Perindustriandan Perdagangan Kota Malang dianalisis menggunakan teori kapasitas inovasi yang terdiri dari 5 (lima) indikator yang dikemukakan oleh Emery et al,.(Emery, n.d.) yang meliputi :

1. Innovative Culture (Budaya Inovatif),

Budaya inovatif merupakan gabungan kreativitas, pemikiran yang terbuka dan menerima ide-ide baru, budaya yang berorientasi inovasi adalah campuran kreativitas, keterbukaan dan memiliki kenginan untuk bereskperimen dan mampu mengambil resiko. Budaya inofatif ini terdiri dari keterbukaan dari pelaksana program yaitu Dinas Koperasi dan Perindustrian Kota Malang dalam memberikan informasi, ide-ide baru yang diberikan terkait materi pelatihan yang diajarkan, kesediaan untuk bereskperimen dari pelaksana dalam menjalankan inovasi sepasar pedas, dan pola pikir pedagang pasar dalam menerima inovasi sepasar pedas

2. Leadership (Kepemimpinan)

Kepemimpinan terlibat dalam menciptakan gambaran baru menjadi lebih komprehensif melalui pengumpulan data,percakapan, aksi, dan pengalaman. Kepemimpinan ini meliputi kecakapan pelakasana dalam mengonsep inovasi Sepasar Pedas, dan sikap dari pelakasana dalam menjalankan tugas pokok dan fungsi pada inovasi sepasar pedas.

\section{Expert Knowledge (Pengetahuan Ahli),}

Menggabungkan pengetahuan, berbagi dan menghasilkan, akan memungkinkan untuk mengembangkan kompetensi organisasi mereka untuk meningkatkan pelayanan yang ada.Pengetahuan ahli ini meliputi kemampuan dari pelaksana program dalam mengatur pedagang dan revitalisasi pasar, serta penciptaan gagasan baru dalam memberikan pelatihan kepada pedagang pasar.

\section{Stakeholders \\ Engagement} (Keterlibatan Stakeholders)

Penyediaan layanan publik dan pelaksanaan manajemen sumber daya manusia dapat mendorong keterlibatan internal (pegawai) dan eksternal (masyarakat) dalam gerakan yang sama menuju hasil yang diharapkan warga negara. 
Keterlibatan stakeholders ini terdiri dari komitmen Dinas Koperasi Perindustrian dan Perdagangan Kota Malang terhadap pedagang pasar, dukungan dari pedagang pasar untuk melaksanakan inovasi sepasar pedas, dan kepercayaan pedagang pasar pada Dinas Dinas Koperasi Perindustrian dan Perdagangan Kota Malang untuk mengatur inovasi sepasar pedas.

\section{Innovative Work Design (Desain Kerja yang Inovatif)}

Sistem kerja yang terstruktur di dalam dan di seluruh organisasi dapat berdampak pada inovasi. Dibutuhkan desain kerja yang inovatif untuk mencapai tujuan dari inovasi sepasar pedas ini, yang didalamnya meliputi:

a. Tingkat kesadaran pedagang pasar akan pentingnya inovasi sepasar pedas.

b. Menjalin kerjasama antara Dinas Koperasi Perindustrian dan Perdagangan Kota Malang dengan pedagang pasar.

c. Hubungan antara Dinas Koperasi Perindustrian dan Perdagangan Kota Malang dengan pedagang pasar bersifat deliberative, dan tidak hanya komunikatif

d. Teknologi yang tepat digunakan untuk mendukung interaksi dan koordinasi antara Dinas Koperasi Perindustrian dan Perdagangan Kota Malang dengan pedagang pasar

Teknik pengumpulan data pada penelitian ini menggunakan teknik observasi, wawancara, dokumentasi dan studi kepustakaan. Adapun analisis data yang digunakan dalam penelitian ini ada empat teknik yaitu dikutip dari model Miles and Huberman(Sugiyono, 2016) keempat teknik tersebut adalah pengumulan data, reduksi data, penyajian data, dan pemaparan atau penarikan kesimpulan.

\section{HASIL DAN PEMBAHASAN}

Dinas Koperasi, Perindustrian dan Perdagangan Kota Malang merupakan lembaga bertipe A yang menyelenggarakan urusan pemerintahan bidang koperasi, bidang perindustrian, bidang usaha mikro, dan bidang perdagangan. Berdasrkan Peraturan Walikota Malang Nomor 15 Tahun 2016 Tentang Perubahan atas Peraturan Walikota Malang Nomor 51, Tahun 2012 Tentang Uraian Tugas Pokok, fungsi dan Tata
Kerja Dinas Perindustrian dan Perdagangan dijelaskan bahwa tugas pokok Dinas Koperasi Perindustrian dan Perdagangan Kota Malang adalah menyusun dan melaksanakan kebijakan urusan pemerintahan daerah dibidang koperasi, perindutrian dan perdagangan.

Untuk meningkatkan kualitas pelayanan, Dinas Koperasi Perindustrian dan Perdagangan Kota Malang menciptakan inovasi Sepasar Pedas. Sepasar Pedas dari kepanjangan Sekolah Pasar Rakyat Pedagang Cerdas merupakan suatu program untuk pedagang pasar tradisional yang bertujuan untuk memberikan keterampilan dan pengetahuan kepada para pedagang pasar pengetahuan kepada pedagang pasar rakyat, melalui training, pembelajaran, pembimbingan, dan bentuk lainnya untuk mengembangan kemampuan dan daya saing tinggi antar pedagang pasar rakyat di era globalisasi, serta untuk memperluas wawasan para pedagang pasar dalam mengelola dan meningkatkan eksistensi pasar tradisional.(Redaksi, n.d.)

Teori inovasi yang digunakan untuk menganalisis program Sepasar Pedas ini adalah komponen kapasitas Inovasi menurut Prof. Y. Emery et al,. dalam Trends and Challenges Towards Innovative Public Services(2015:4-10) yang meliputi Innovative Culture (Budaya Inovatif),Leadership (Kepemimpinan), Expert Knowledge (Pengetahuan Ahli), Stakeholders Engangement (Keterlibatan Stakeholders)dan Innovative Work Design (Desain Kerja yang Inovatif)yaitu sebagai berikut :

\section{Innovative Culture (Budaya Inovatif)}

Budaya inovatif adalah gabungan dari pola pikir yang kreativ, terbuka dan perolehan gagasan-gasan baru dianatara para pemimpin dan pemangku kepentingan eksternal

Inovasi berkaitan dengan kegiatan menciptakan transisi dan renovasi. Perubahan juga diartikan memperkenalkan sesuatu yang baru dari sesuatu yang lama dan menuju pada suatu hal yang mengarah lebih efektif. Perubahan tidak terlepas dari sikap inovatif yang menuntun untuk menciptakan, mempublikasikan dan menerapkan hal-hal baru.(Umam, 2014)

Berdasarkan hasil wawancara dan observasi yang dilakukan, penulis melihat bahwa Dinas Koperasi Perindustrian dan Perdagangan Kota Malang telah menerapkan budaya inovatif. Seperti yang dikatakan oleh Ibu Eka selaku Kepala Seksi Bidang Pengendalian dan Pengawasan Dinas Koperasi Perindustrian dan Perdagangan Kota Malang. Berikut wawancaranya: 
"Pada pasar Oro-Oro Dowo yang telah menerapkan inovasi ini sudah mulai gampang menerima hal-hal baru mbak, seperti melakukan transaksi dengan non tunai, kemudian menggunakan trolly dalam berbelanja dan lain sebagainya." (wawancara 23 September 2020)

Kegiatan Sepasar Pedas ini dilaksanakan di lorong pasar pada pukul 13.00 WIB atau setelah pedagang tutup toko. Sepasar Pedas ini dilaksanakna siang hari agar tidak mengganggu aktivitas pasar yang ramai di pagi hari.

Dalam inovasi tersebut juga terdapat beberapa kegiatan yang dilakukan setiap minggunya. Khususnya kegiatan pokok dari program ini yaitu sekolah pasar rakyat yang dilaksanakan satu minggu dua kali. Kegiatan sekolah pasar rakyat ini berisi pemberian materi tentang bagaimana menjadi pedagang yang cerdas dan mengedukasi para pedagang pasar tradisonal akan pentingnya menjaga kebersihan dan kualitas pasar untuk meningkatkan eksistensi pasar tradisional. Kemudian bentuk lain dari Sepasar Pedas ini yaitu berupa pendampingan terkait pelaksanaan teknis penggunaan alat baru seperti penggunaan mesin $E D C$ dan tata cara penjualan online di market place.

Dinas Koperasi Perindustrian dan Perdagangan Kota Malang melalui inovasi ini juga telah menerapkan perilaku inovatif kepada para pegawainya. Dengan adanya inovasi ini pegawai dari Dinas Koperasi Perindustrian dan Perdagangan Kota Malang dituntut untuk bereksperimen mengembangkan dan menghasilkan ide-ide baru setiap minggunya dalam menyusun materi yang akan disampaikan pada kegiatan sekolah pasar rakyat.

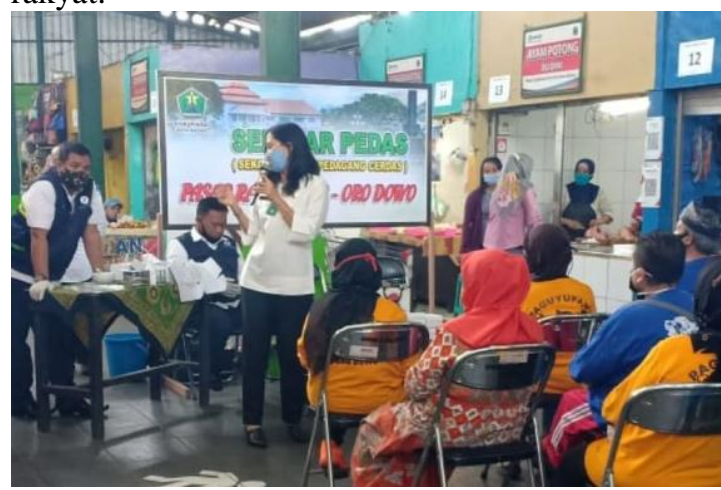

Gambar 1

Pemaparan materi Sepasar Pedas di Pasar OroOro Dowo Kota Malang

Sumber : Facebook Diskopindag Kota Malang 2020 Adanya Sepasar Pedas ini juga mampu merubah pola pikir pedagang pasar akan pentingnya mempertahankan pasar tradisional dan membuat para pembelinya nyaman untuk tetap berbelanja di pasar. Dimana Dinas Koperasi Perindustrian dan Perdagangan Kota Malang dalam hal ini mengedukasi pedagang pasar untuk berfikir cerdas dalam memasarkan dagangannya dan menarik minat pembilnya.

\section{Leadership ( Kepemimpinan )}

Pada kepemimpinan membutuhkan kemampuan manajerial tertentu dan proses organisasi. Kemampuan organisasi ini bergantung pada manajer publik yang mampu memfasilitasi perubahan dengan menghasilkan makna dan membaginya dengan pemangku kepentingan internal dan eksternal. Kepemimpinan ini meliputi kecakapan pelakasana dalam mengonsep inovasi Sepasar Pedas, dan sikap dari pelakasana dalam menjalankan tugas pokok dan fungsi pada inovasi sepasar pedas.

Menurut Wahjosumidjo, kepemimpinan adalah kompetensi seseorang seperti kepribadian, ketrampilan, dan kecakapan. Kepemimpinan juga erat kaitannya dengan gaya, sikap dan jabatan pemimpin yang bersangkutan dan korelasi dengan para pengikutnya serta situasi.(Dtf, 2020)

Dinas Koperasi Perindustrian dan Perdagangan Kota Malang bertanggung jawab sebagai koordinator yang memanjemen seluruh kegiatan yang berkaitan dengan program Sepasar Pedas. Dinas Koperasi Perindustrian dan Perdagangan Kota Malang juga bertugas mengonsep dan mempersiapkan materi yang akan disampaikan kepada para pedagang pasar.

Dibawah Kepemimpinan Kepala Bidang Perdagangan Sapto Wibowo, S.H., M.Hum. mengalami peningkatan penilaian kinerja. Program Sepasar Pedas ini telah berjalan selama 3 tahun. Dan dalam kurun waktu tersebut, Sepasar Pedas telah meraih penghargaan dua kali. Yang pertama yaitu pada tahun 2019 sebagai Top 25 Inovasi Pelayanan Publik Jawa Timur. Dan yang kedua pada tahun 2020 ini menjadi Top 45 Inovasi pelayanan publik yang diselenggarakan oleh Kementerian Pendayagunaan Aparatur Negara dan Reformasi Birokrasi (PANRB).

Seperti yang disampaikan Ibu Eka selaku Kepala Seksi Bidang Pengendalian dan Pengawasan Dinas Koperasi Perindustrian dan Perdagangan Kota Malang, sebagai berikut :

"Iya mbak, inovasi ini tercetus pada tahun 2017, mulanya ide ini dari bidang perdagangaan khususya bagian pengendalian dan pengawasan, kemudian ide ini dirapatkan dengan pak kepala dinas, sampai akhirnya disetujui dan 
dilaksanakanlah inovasi ini. Dan alhamdulillah pada tahun 2019 inovasi ini penghargaan dan apresiasi dari pmerintah Jawa Timur, maka dari itu kita setiap bulannya selalu koordinasi sama pedagang pasar dan rapat ruitinan untuk mengembangkan inovasi ini. Bahkan biasanya walikota Malang juga melakukan kunjungan ke Pasar Oro-Oro Dowo" (wawancara 23 September 2020)

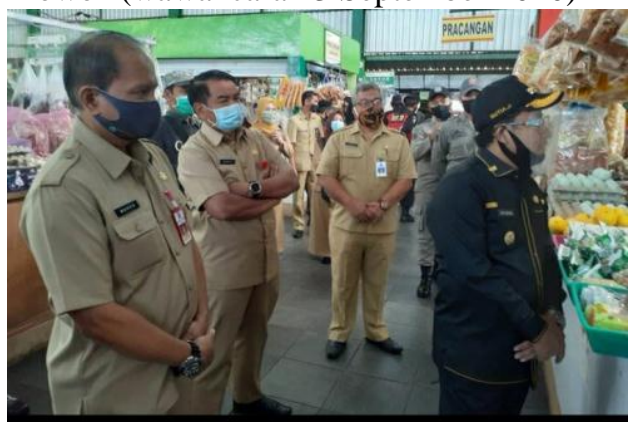

Gambar 2

Kunjungan Walikota Malang Ke Pasar Oro-Oro Dowo

Sumber : Instagram Diskopindag Malang 2020

Dari temuan penulis, sikap dari para pegawai Dinas Koperasi Perindustrian dan Perdagangan Kota Malang juga menunjukan sikap positif dalam melaksanakan inovasi Sepasar Pedas ini, dilihat dari perilaku pegawainya yang telah menjalankan tugas pokok dan fungsinya yang sesuai dengan peraturan yang berlaku.

\section{Expert Knowledge (Pengetahuan} Ahli)

Pengetahuan adalah sumber daya yang memenuhi syarat untuk menjadi sumber daya yang strategis. Dengan mengelola pengetahuan, perusahaan atau organisasi telah berusaha memanajmen pengetahuan dari dalam dan memperoleh pengetahuan dari luar yang diperlukan untuk menghasilkan terobosan-terobosan.(Munir, 2010)

Menggabungkan pengetahuan, berbagi dan menghasilkan, akan memungkinkan untuk mengembangkan kompetensi organisasi mereka untuk meningkatkan pelayanan yang ada atau memajukan yang baru. Pengetahuan didistribusikan secara acak di beberapa sumber internal dan eksternal. Oleh karena itu mengelola pengetahuan di Administrasi Publik membutuhkan penambahan ruang yang diberikan untuk pertukaran pengetahuan antara pemangku kepentingan yang relevan.

Pada inovasi Sepasar Pedas ini ahli yang dimaksud adalah staf ahli dibidang perdagangan di
Dinas Koperasi Perindustrian dan Perdagangan Kota Malang, yaitu para pegawai dari bidang perdagangan yang didalamnya terdiri dari beberapa seksi atau sub bidang yang nantiya membantu mempermudah mencapai tujuan. Dimana dalam pelaksanaanya perlu sumber daya yang mumpuni untuk memberikan ide-ide baru terkait pengembangan dan peningkatan eksistensi pasar tradisional secara inovatif dan efektif. Pemilihan tenaga ahli ini dimaksudkan agar inovasi ini dapat tepat sasaran dan berguna bagi pedagang pasar tradisional.

Selain sumber daya dari bidang perdagangan, bidang lain seperti bidang perindustrian dan koperasi juga dibutuhkan dalam pelaksanaan inovasi ini. Karena jika materi yang diajarkan lebih bervariatif, maka juga akan memperluas pengetahuan para pedagang pasar. Hal ini dibuktikan dengan hasil wawancara dengan Ibu Eka selaku Kepala Seksi Bidang Pengendalian dan Pengawasan Dinas Koperasi Perindustrian dan Perdagangan Kota Malang. Berikut wawancaranya : "Kalau utuk memberikan materi dan memanajemen inovasi ini ya dari bidang perdagangan pasti ya mbak, kita secara bergantian menjadi pemateri, kemudian kita berkoordinasi dengan kepala pasar dan setiap bulannya kita juga rutin melakukan evaluasi, apakah ada kendala atau permintaan pedagang pasar itu yang seperti apa begitu" (wawancara 23 September 2020)

Untuk mengasah kemampuan para pegawainya, Dinas Koperasi Perindustrian dan Perdagangan Kota Malang juga tak jarang mengirim pegawainya secara bergantian untuk mengikuti kegiatan diklat dan rapat kerja.

Melalui peningkatan kemampuan dan kompetensi ini, diharapkan mutu pelayanan yang dihasilkan oleh pegawai yang bersangkutan juga meningkat.(Triyono, Nikita Bakuh \& Niswah, 2015)

Dilihat dari pencapaian yang telah diraih oleh Dinas Koperasi Perindustrian dan Perdagangan Kota Malang, khususnya pada inovasi Sepasar Pedas, kepemimpinan yang sekarang mampu meningkatkan eksistensi pasar tradisional ditengah persaingan pasar bebas sekarang ini.

\section{Stakeholders Engagement} (Keterlibatan Stakeholders)

Keterlibatan yang tinggi dari manajemen sumber daya manusia merupakan sinyal nyata dari dukungan, kepercayaan, dan komitmen perusahaan atau organisasi terhadap pegawainya. Dengan cara yang sama, keterlibatan pemangku kepentingan 
eksternal muncul sebagai salah satu bahasan pokok dalam literatur yang didedikasikan untuk Administrasi Publik. Keterlibatan stakeholders ini terdiri dari komitmen Dinas Koperasi Perindustrian dan Perdagangan Kota Malang terhadap pedagang pasar, dukungan dari pedagang pasar untuk melaksanakan inovasi sepasar pedas, dan kepercayaan pedagang pasar pada Dinas Dinas Koperasi Perindustrian dan Perdagangan Kota Malang untuk mengatur inovasi sepasar pedas.

Dinas Koperasi Perindustrian dan

Perdagangan Kota Malang dalam meingimplementasikan inovasi ini tidak hanya melibatkan pegawai atau sumber daya dari internal saja. Namun juga melibatkan sumber daya eksternal. Sumber daya ekternal ini dilibatkan ketika pemeberian materi dalam Sepasar Pedas yang berkaitan dengan hal diluar bidang perdagangan. Seperti pemberian materi tentang pentingnya menjaga kebersihan dan kesehatan di pasar tradisional di masa pandemi. Maka dalam hal ini Dinas Koperasi Perindustrian dan Perdagangan Kota Malang melibatkan anggota dari Dinas Kesehatan Kota Malang. Seperti yang disampaikan oleh Ibu Eka selaku Kepala Seksi Bidang Pengendalian dan Pengawasan Dinas Koperasi Perindustrian dan Perdagangan Kota Malang. Sebagai berikut :

"Untuk pelibatan stakeholders, kita juga bekerja sama dengan Dinas Kesehatan Kota Malang mbak sepertti pemberian materi yang berkaitan dengan menjaga kebersihan, terus karena ada pandemi ini jadi disampaikan materi tentang protokol covid19. Kemudian kita juga bekerjasama dengan bank Jatim untuk pembayaran e-retribusi. Jadi untuk mengatasi kebocoran atau kecurangan kita sudah menerapakan eretribusi yang dibantu oleh bank Jarim. Lalu kita juga bekerjasama dengan bank-bank swasta maupun negeri terkain transaksi non tunai, karena di pasar oro-oro dowo kan sudah bisa melakukan transaksi dengan mesin edc ya mbak, lalu juga dengan scan barcode juga bisa. Terus juga kemarin kita mendapatkan bantuan juga dari BPD Jatim berupa masker, sarung tangan plastik, hand sanitizer, dan wastafel untuk cuci tangan."

(wawancara 23 September 2020)

Pelibatan dari pihak eksternal ini bertujuan agar pembuatan dan penyampaian materi dapat diolah sesuai ahli dibidangnya.

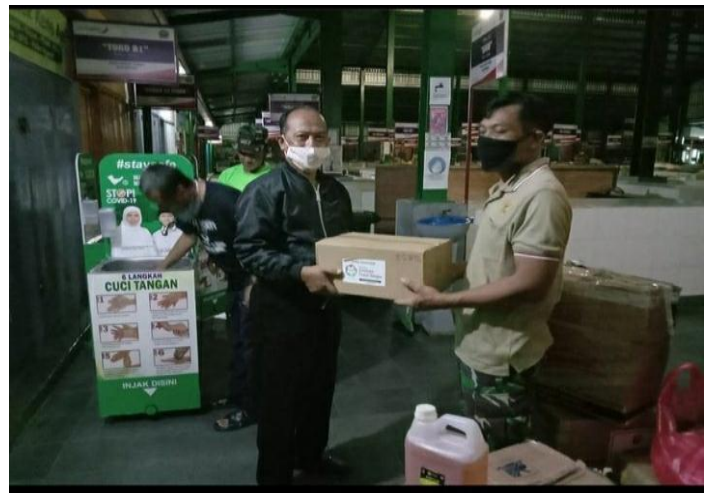

Gambar 3

Pemberian Bantuan dari BPD Jatim untuk pasar oro-oro dowo Malang

Sumber : Instagram Diskopindag Malang 2020

Keterlibatan stakeholders juga berkaitan dengan komitmen Dinas Koperasi Perindustrian dan Perdagangan Kota Malang terhadap pedagang pasar. Berdasarkan temuan penulis dilapangan, pedagang pasar mendukung penuh adanya program ini. Mulanya hanya beberapa pedagang pasar saja yang mengikuti serangkaian kegiatan dalam program Sepasar Pedas ini, namun setelah melihat hasil serta perubahan yang dicapai dari adanya inovasi ini, pedagang pasar yang lainnya pun ikut dalam kegiatan inovasi ini. Sehingga inovasi ini meraih penghargaan yang membanggakan.

Ibu Sulami selaku pedagang di Pasar OroOro Dowo mengatakan, setelah adanya inovasi ini para pedagang lebih berwawasan luas pada pengelolaan pasar yang baik dan seperti ikut memiliki pasar tersebut. Ia berharap program ini terus berjalan dan kedepannya banyak kegiatan yang bermanfaat lainnya.

Pada indikator keterlibatan stakeholders ini Dinas Koperasi Perindustrian dan Perdagangan Kota Malang telah cukup baik melakukan kerjasama dan pelibatan pihak ekseternal, namun kedepannya mungkin bisa memperluas relasi.

\section{Innovative Work Design (Desain} Kerja yang Inovatif)

Infrastruktur yang mudah menyesuaikan adalah tingkatan yang tidak berjenjang, memperpendek otoritas formal, mengurangi rutinitas dan penyeragaman serta kerjasama. Selain memberdayakan sumber daya manusia, penting untuk mendesain ulang organisasi. Pola kerja yang tertata di dalam dan di seluruh organisasi dapat berpengaruh pada inovasi ini.(Emery, n.d.)

Dibutuhkan desain kerja yang inovatif untuk mencapai tujuan dari inovasi sepasar pedas ini, yang didalamnya meliputi:

a. Tingkat kesadaran pedagang pasar akan pentingnya inovasi Sepasar Pedas. 
Pentingnya meningkatkan eksistensi pasar tradisonal membuat para pedagang pasar semakin antusias mengikuti program Sepasar ini. Berdasarkan temuan penulis, tingkat kesadaran pedagang pasar pada inovasi ini semakin meningkat. Ditunjukkan dengan sikap pedagang pasar yang bersemangat dalam mengikuti kegitan-kegiatan dari inovasi Sepasar Pedas. Dalam hal ini pedagang pasar telah mampu memahami pentingnya mempertahankan pasar tradisional ditengah persaingan pasar bebas. Dengan tingkat kesadaran pedagang pasar yang tinggi, mampu merubah pola pikir pedagang pasar dalam mengembangkan pasar tradisional dan membuat para pedagang mempunyai rasa memiliki terhadap pasar tersebut.

b. Menjalin kerjasama antara Dinas Koperasi Perindustrian dan Perdagangan Kota Malang dengan pedagang pasar.

Untuk mencapai tujuan yang efektif dan desain kerja yang inovatif, maka perlu membangun kerjasama yang baik antara pelaksana dan kelompok sasaran. Dimana tujuan dari kerjasama adalah untuk mempercepat tujuan yang diingingkan dan mendorong pihak-pihak yang terlibat agar dapt bekerja lebih produktif dan efisien.(Dalma, 2020)

Dari temuan penulis, Dinas Koperasi Perindustrian dan Perdagangan Kota Malang telah melakukan kerjasama yang baik dengan pedagang pasar. Hal ini dibuktikan dengan diraihnya dua penghargaan dari inovasi sepasar pedas ini dalam 2 tahun terakhir. Penghargaan yang diraih menunjukkan bahwa pedagang pasar dan Dinas Koperasi Perindustrian dan Perdagangan Kota Malang telah membangun kepercayaan dan menanamkan saling memiliki dalam melaksanakan program ini, sehingga tujuan dari program ini cepat dicapai dan mendapat apresiasi.

c. Hubungan antara Dinas Koperasi Perindustrian dan Perdagangan Kota Malang dengan pedagang pasar bersifat deliberative, dan tidak hanya komunikatif.

Secara epistimologi deliberative berasal dari kata "deliberasi" yang artinya konsultasi atau menimbang-nimbang. Dalam konteks politik Indonseia juga bisa diartikan sebagai musyawarah.(Tetiro, 2016)

Dalam hal ini Dinas Koperasi Perindustrian dan Perdagangan Kota Malang dan pedagang pasar telah menerapkan sifat deliberative. Berdasarkan hasil wawancara penulis, untuk menyusun kegiatan dan SOP dalam inovasi Sepasar Pedas ini, Dinas Koperasi Perindutrian dan Perdagangan Kota Malang juga melakukan musyawarah dan melibatkan pedagang pasar untuk menyusunnya, karena saran dan pendapat dari pedagang sangat dibutuhkan, agar inovasi sepasar pedas ini menguntungkan semua pihak.

d. Teknologi yang tepat digunakan untuk mendukung interaksi dan koordinasi antara Dinas Koperasi Perindustrian dan Perdagangan Kota Malang dengan pedagang pasar.

Untuk mendukung kegiatan dalam inovasi Sepasar Pedas maka perlu adanya sarana dan prasarana yang menunjang. Salah satu sarana yang penting yaitu penggunaan teknologi. Dimana di era yang sekarang ini perkembangan teknologi semakin pesat untuk mempermudah pekerjaan dan tujuan yang observasi penulis, Dinas Koperasi Perindustrian dan Perdagangan Kota Malang telah memanfaatkan teknologi dengan cukup baik dalam program Sepasar Pedas ini. Hal ini dibuktikan dengan diterapkannya eretribusi pasar. Walaupun belum semua pasar di Kota Malang menggunakannya, namun beberapa pasar telah menerapkannya. Yang mana dengan diterapkannya e-retribusi ini telah menunjukan bahwa pasar tersebut telah melakukan terebosan baru dalam mengurangi timbulnya kebocoran Pendapatan Asli Daerah. Selain itu pada Pasar Oro-Oro Dowo yang telah menerapkan inovasi ini juga telah menggunakan mesin EDC (Electronic Data Capture) dalam melakukan transaksi jual beli. Penggunaan mesin EDC ini juga dimaksudkan agar mempermudah dalam melakukan pembayaran, karena konsumen tidak perlu memakai uang tunai. 


\section{PENUTUP}

\section{Simpulan}

Berdasarkan hasil wawancara dan temuan data dilapangan serta studi literarur yang telah disajikan, maka deskripsi dan analisis Inovasi Sekolah Pasar Rakyat Pedagang Cerdas oleh Dinas Koperasi Perindustrian dan Perdagangan Kota Malang telah sesuai dengan komponen kemampuan inovasi menurut Prof. Y. Emery et al, dalam Trends and Challenge Towards Innovative Public Services (2015:4-10). Hal tersebut dibuktikan pada masingmasing komponen yang telah tercapai.

Komponen yang pertama yaitu Innovative culture (budaya inovatif). Pada inovasi sepasar pedas budaya inovatif telah diterapkan pada Dinas Koperasi Perindustrian dan Perdagangan Kota Malang dalam menciptakan ide-ide baru terkait kegiatan yang dilaksanakan dalam sekolah pasar rakyat pedagang cerdas. Komponen yang kedua yaitu Leadership (kepemimpinan). Setelah adannya Sepasar Pedas Dinas Koperasi Perindustrian dan Perdagangan Kota Malang telah mengalami pengingkatan kinerja, ditunjukkan dengan diraihnya beberapa penghargaan dan sikap positif dari pegawai dan pedagang pasa yang melaksanakan program Sepasar Pedas ini. Komponen selanjutnya yaitu Expert Knowledge (Pengetahuan Ahli). Pengethuan ahli ini terkait dengan kemampuan pelaksana dalam menjalakan program. Pada Sepasar Pedas ini pengetahuan ahli yang dimaksud yaitu pegawai Dinas Koperasi Perindustrian dan Perdagangan Kota Malang khsusnya dibidang Perdagangan. Komponen yang keempat yaitu Stakeholders Engagement (Keterlibatan Stakeholders). Pada inovasi Sepasar Pedas ini Dinas Koperasi Perindustrian dan Perdagangan Kota Malang melibatkan berbagai pihak untuk mendukung kelancaran berjalannya program Sepasar Pedas ini. Dan komponen yang terakhir yaitu komponen yang kelima adalah Innovative Work Design (Desain Kerja yang Inovatif). Dinas Koperasi Perindustrian dan perdaganagn Kota Malang dengan pedagang pasar telah melakukan kerja sama yang baik dan memiliki kesadaran yang tinggi akan pentingnya inovasi ini.

Setelah adanya inovasi Sepasar Pedas eksitensi pasar tradisonal lebih meningkat, seperti yang sudah dijelaskan sebelumnya, pasar oro-oro dowo menjadi pasar icon Jawa Timur setalah adanya inovasi ini. Meskipun Dinas Koperasi
Perindustrian dan Perdagangan Kota Malang telah memenuhi komponen kempuan inovasi, namun masih terdapat kekurangan dan kendala yang dihadapi. Kendal-kendala tersebut diantaranya yaitu sampai saat ini hanya dua pasar saja yang diterapkan inovasi ini yaitu Pasar Oro-Oro Dowo dan Pasar Dinoyo. Selain itu masih kurangnya keterlibatan stakeholders dalam pengembangan inovasi. Tetapi secara keseluruhan, Sepasar Pedas telah memberikan banyak manfaat diantaranyayaitu meningkatnya mutu pelayanan bagi pedagang pasar dan masyarakat, serta dapat dijadikan percontohan oleh kota-kota lain.

\section{Saran}

Berdasarkan kesimpulan diatas, maka peneliti memberikan saran terhadap inovasi layanan Sekolah Pasar Rakyat Pedagang Cerdas di Dinas Koperasi Perindustrian dan Perdagangan Kota Malang sebagai berikut:

a. Untuk kedepannya Sepasar Pedas ini dapat diterapkan di semua pasar di Kota Malang, karena dari 26 pasar masih dua pasar saja yang menerapkan inovasi ini.

b. Dapat memperluas kerjsama dan melibatkan berbagai pihak lain dalam mengembangangkan inovasi ini, sehingga materi yang diberikan pada Sepasar Pedas semakin beragam dan dapat meningkatkan wawasan pedagang pasar tradisional.

c. Memberikan sarana dan prasarana yang lebih baik untuk kegiatan Sepasar Pedas, seperti tempat yang luas dan nyaman pada saat penyampaian materi.

\section{Ucapan Terimakasih}

Penulis mengucapkan terimakasih kepada pihak-pihak yang berkontribusi dalam penulisan jurnal ini diantaranya:

a. Seluruh dosen S1 Administrasi Negara FISH Unesa.

b. Fitrotun Niswah, S.AP., M.AP selaku dosen pembimbing.

c. Dra. Meirinawati, M.AP. dan Trenda Aktiva Oktariyanda, S.AP., M.AP. selaku dosen penguji.

d. Pihak-pihak lainnya yang memberi dukungan baik secara moral maupun dukungan moril kepada peneliti. 


\section{DAFTAR PUSTAKA}

Andriani, Maritfa Nika \& Ali, M. M. (2013). Kajian Eksistensi Pasar Tradisional Pasar Surakarta. Medical Hypotheses, 30(3), 203-210. https://doi.org/10.1016/0306-9877(89)90062-5

Anggraeny, C. (2013). Imovasi Pelayanan Kesehatan. 1, 85-93.

Arianty, N. (2013). Analisis Perbedaan Pasar Modern Dan Pasar Tradisional Ditinjau Dari Strategi Tata Letak (Lay Out) Dan Kualitas Pelayanan Untuk Meningkatkan Posisi Tawar Pasar Tradisional. Jurnal Manajemen \& Bisnis, 13(01), 12.

Dalma, M. A. (2020). Kerjasama-Pengertian, Tujuan, Manfaat, Contoh Kerjasama _ dosenpintar.

Dtf, A. (2020). PENGERTIAN KEPEMIMPINAN: Tujuan, Teori, Fungsi dan Contoh Leadership. February 9.

Emery, Y. dkk. (n.d.). Trends \& Challenges. 1-14.

Eprilianto, D. F., Sari, Y. E. K., \& Saputra, B. (2019). Mewujudkan Integrasi Data Melalui Implementasi Inovasi Pelayanan Kesehatan Berbasis Teknologi Digital. JPSI (Journal of Public Sector Innovations), 4(1), 30. https://doi.org/10.26740/jpsi.v4n1.p30-37

Firdausi, A. C. (2019). Inovasi "Sepasar Pedas" Kota Malang Masuk Top 25 Inovasi Pelayanan Publik Jatim, Seperti Apa Sih? Jatim News, p. 1. https://doi.org/https://jatimtimes.com/baca/207 035/20191230/195000/inovasi-sepasar-pedaskota-malang-masuk-top-25-inovasi-pelayananpublik-jatim-seperti-apa-sih

Haqie, Z. A., Nadiah, R. E., \& Ariyani, O. P. (2020). Inovasi Pelayanan Publik Suroboyo Bis Di Kota Surabaya. JPSI (Journal of Public Sector Innovations), 5(1), 23. https://doi.org/10.26740/jpsi.v5n1.p23-30

Munir, N. S. (2010). Penerapan Manajemen Pengetahauan di Perusahaan di Indonesia. Mba, 1-13.

Nugroho, R. A., S, K., Nurhaeni, I. D. A., \& Utami, W. A. (2017). Traditional Market Sellers Acceptance of Electronic Government System. 2017 International Conference on Information Management and Technology (ICIMTech), (November), 284-287.
Pym, D., Taylor, R., \& Tofts, C. (2007). Public services innovation through technology. Portland International Conference on Management of Engineering and Technology, 2736-2739. https://doi.org/10.1109/PICMET.2007.4349609

Redaksi, T. (n.d.). Inovasi "Sepasar Pedas" Kota Malang Masuk Top 25 Inovasi Pelayanan Publik Jatim, Seperti Apa Sih_ _ _ Indonesia Online News. Indonesia Online.

Sembiring, L. J. (2018). Ada 6 Pasar Rakyat Baru Bersertifikat SNI. Retrieved from https://economy.okezone.com/read/2018/01/31/ 320/1852795/ada-6-pasar-rakyat-barubersertifikat-sni

Soewadji, J. (2012). Pengantar Metodelogi Penelitian. Bogor: Mitra Wacana Media.

Sugiyono. (2012). Memahami Penelitian Kualitatif. Bandung: ALFABETA.

Sugiyono. (2016). Memahami Penelitian Kualitatif. Bandung: Alfabeta.

Suriyani, E. (2017). KECAMATAN HALONG KABUPATEN BALANGAN. 4(1), 113-131.

Tetiro, A. (2016). Deliberasi dan Representasi.

Triyono, Nikita Bakuh \& Niswah, F. (2015). Inovasi Pelayanan Kesehatan Lansia melalui Program Gerakan Lansia Sehat ( Gelas ) di Puskesmas Trenggalek Kabupaten Trenggalek Nikita Bakuh Triyono S1 Ilmu Administrasi Negara, Fakultas Ilmu Sosial dan Hukum, Universitas Negeri Surabaya Fitrotun Niswah.

Umam, K. (2014). Analisis Budaya Inovasi Dalam Menciptakan Perilaku Inovatif Karyawan Pada Naura Collection Probolinggo. Skripsi, 8(33), 44.

Peraturan Walikota Malang Nomor 15 Tahun 2016 Tentang Perubahan atas Peraturan Walikota Malang Nomor 51, Tahun 2012 Tentang Uraian Tugas Pokok, fungsi dan Tata Kerja Dinas Perindustrian dan Perdagangan 
Publika. Volume 9 Nomor 2 Tahun 2021, 1-12 